\title{
Social presence in an Emergency Remote Teaching (ERT) in English during Covid-19
}

La Presencia Social en una Enseñanza Remota de Emergencia (ERT) en Inglés durante Covid-19

\section{Sergio Alonso Lopera ${ }^{2 *}$}

Universidad de Antioquia, Colombia

1 Received: September 23rd 2020/ Accepted: October 22nd 2021

2 sergio.lopera@udea.edu.co 


\section{Abstract}

Many educational institutions had to move their face-to-face modality to online modality in a sudden way due to coronavirus disease 2019 (Covid-19). Following the principles of qualitative research, on this reflection a foreign language teacher describes his social experience in an Emergency Remote Teaching (ERT) when he moved his face-to-face classes to online ones. Based on Rourke et al's (2001) and Swan's (2019) social presence, three elements were found on his online experience: cohesive teaching strategies, affective teaching strategies, and interactive teaching experiences. Asking about students' mental health, giving advice, and keeping the video on were some of the strategies used. Conclusions suggest that it is vital to present people as human beings and touch their own realities during pandemic times. Recommendations involve not only including evaluation practices such as take-home exams, self-assessment and peerassessment, but also monitoring the ongoing process during emergency times.

Keywords: Covid-19; social presence; Emergency Remote Teaching (ERT); teaching English

\section{Resumen}

Muchas instituciones educativas tuvieron que mover sus clases presenciales a virtuales de una manera abrupta debido a la pandemia causada por el coronavirus 2019 (Covid-19). En esta reflexión, un profesor de inglés como lengua extranjera describe su experiencia social en una Enseñanza Remota de Emergencia (ERT) cuando hizo el cambio de la modalidad presencial a la virtual. Basado en la presencia social descrita por Rourke et al. (2001) y Swan (2019), tres elementos se encontraron en su experiencia pedagógica: estrategias de enseñanza cohesivas, estrategias de enseñanza afectivas y estrategias de enseñanza interactivas. Algunos de los ejemplos de estas estrategias incluyen preguntar por la salud mental de los estudiantes, brindar consejos y mantener la videocámara encendida. Las conclusiones sugieren que es de gran importancia que los participantes se presenten como seres humanos y toquen sus propias realidades durante los tiempos de la pandemia. Las recomendaciones incluyen no solo realizar prácticas evaluativas como la autoevaluación, la evaluación por pares y el examen para realizar en casa, sino también monitorear el proceso durante los tiempos de emergencia.

Palabras clave: Covid-19; presencia social; Enseñanza Remota de Emergencia (ERT); enseñanza de inglés 


\section{Resumo}

Muitas instituições educativas tiveram que mover suas aulas presenciais a virtuais de uma forma abrupta devido à pandemia causada pelo coronavírus 2019 (Covid-19). Nesta reflexão, um professor de inglês como língua estrangeira descreve sua experiência social em um Ensino Remoto de Emergência (ERT) quando fez a mudança da modalidade presencial à virtual. Baseado na presença social descrita por Rourke et al. (2001) e Swan (2019), três elementos se encontraram em sua experiência pedagógica: estratégias de ensino coesivas, estratégias de ensino efetivas e estratégias de ensino interativas. Alguns dos exemplos destas estratégias incluem perguntar pela saúde mental dos estudantes, dar conselhos e manter a videocâmara ligada. As conclusões sugerem que é de grande importância que os participantes se apresentem como seres humanos e toquem suas próprias realidades durante os tempos da pandemia. As recomendações incluem, não só realizar práticas avaliativas como a autoavaliação, a avaliação por pares e a prova para realizar em casa, mas também monitorar o processo durante os tempos de emergência.

Palavras chave: Covid 19; presença social; Ensino Remoto de Emergência (ERT); ensino de inglês 


\section{Introduction}

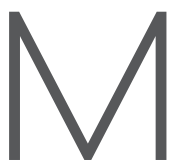

any educational institutions had to move their face-to-face modality to online modality in a sudden way due to COVID-19. In December 2019, a transmittable viral infection called the coronavirus disease 2019 (COVID-19) emerged in Wuhan, China, and spread rapidly around the world. Thus, the World Health Organization (WHO) declared the novel COVID-19 outbreak global pandemic in March 2020. As a result of this situation, both teachers and students had to consider new things and redefine their teaching and learning processes.

One of the considerations about the change from face-to-face modality to online modality has to do with participants' expectations. Traditional identities, new roles, new environment, different workloads and material redesign are some of the expectations issues that are involved (Redmon, 2011). The second element involves developing some skills in the online modality such as the recognition of the interface, online interaction, autonomy, access, control of information, and creativity, among others. Due to the sudden change from face-to-face modality to online modality, it is important to take into account the notion of remote teaching/learning. The MerriamWebster online dictionary defines the word 'remote' as separated by an interval or space greater than usual. In this sense, remote teaching/learning implies delivering/receiving educational content physically away from the institution of learning (Nokukhanya, Chuks \& Masuku, 2021). Remote teaching/learning also means to be "flexible, free, and welcoming, non-prejudiced, non-restricted and unfettered" (Blessinger and Bliss, 2016). During Covid-19 times, most of the delivering/receiving educational content has been given via online and Hodges, Moore, Lockee, Trust and Bond (2020) make a difference between well planned online learning and online learning in this time of emergency. The former involves training, time for preparation, and support from experts, whereas the latter has to do with something that is not planned beforehand, that is to say, improvisation.

As a way to respond to these difficult times in education, Hodges et al. (2020) highlight the concept of Emergency Remote Teaching (ERT) for those teachers who had to become online tutors without any virtual experience. The authors state that

The primary objective in these circumstances is not to re-create a robust educational ecosystem but rather to provide temporary access to instruction and instructional supports in a manner that is quick to set up and is reliably available during an emergency or crisis (Hodges et al., 2020).

Thus, educators must look for delivery modes, alternatives, and resources that help them keep on working with students. One of the suggestions to align with ERT is to follow the evaluation mode of CIPP (Context, Input, Process, Product). Evaluation of 
needs, problems, and opportunities (Context); evaluation of an action plan, the strategy of a program, and budget (Input); evaluation of the process that aims at monitoring, documenting, assessing, and reporting on the implementation of plans (Process); and the evaluation of costs and benefits (Product) are the recommended steps to give students temporary access to learn and attend classes during the quarantine caused by COVID-19. Finally, the authors also suggest that teachers be flexible with deadlines for assignments, lessen the requirements for some tasks, and apply both formative and alternative assessment (Shohamy, 2001; Picón-Jácome, 2013).

One of the key elements in online modality has to do with social presence. Garrison, Anderson, and Archer (2001) argue that it is vital that participants project their personal characteristics as real people although the communication is given through technological tools. Besides, it is important to create social presence as this motivates participants to interact with each other. When students perceive that they are part of a virtual group and their ideas are taken into account, they tend to participate more, and learning is given. In fact, different studies support that learning and satisfaction are connected when participants feel social presence in an online modality (Mykota \& Duncan, 2007; Esani, 2010; Rovai, 2002; Sung \& Mayer, 2012, Swan \& Shih, 2005; Swan, 2019). Rourke, Anderson, Garrison and Archer (2001) divide social presence into three categories: affective responses, cohesive responses, and interactive responses. Affective responses involve feelings, emotions, values, beliefs (e.g., sharing personal information, using humor, using descriptive words, giving a point of view). Cohesive responses deal with communication issues that maintain the participants united (e.g., greetings, the way of addressing, social sharing). Finally, interactive responses have to do with issues that support that others are attending the course (e.g., acknowledgment, agreement/disagreement, approval, invitation).

\section{Methodology and context}

This reflection follows the principles of a case study (Creswell, 2014; Yin, 2003), as I wanted to have an intense inquiry about my own teaching practices during Covid-19 times. Since this a new experience and I describe real-life situations, this case study is also based on the interpretative approach (Stake, 1998). Finally, my teaching practice targets qualitative research because I wanted to understand the social presence in my real teaching.

Regarding participants, they were a group of beginners in a public university in Medellín-Colombia. 21 undergraduate students attended the course and age ranged between 18 and 22 years old. The methodology followed the communicative approach (Canale \& Swain, 1980; Celce-Murcia, Dornyei \& Thurrell, 1995; Instituto Cervantes, 2002; Savignon, 2001) and the thematic units for this course included personal 
matters, family ties, and home and folks. Finally, the course lasted 64 hours and when we changed to online modality 20 hours were covered face-to-face and 44 were taught in an online way.

\section{My ERT social presence during Covid-19}

During my COVID-19 quarantine, my ERT involved interactions, emotions, and communicative issues. Based on Rourke et al. (2001) and Swan (2019), I summarize the social presence strategies I used in my foreign language teaching:

Table 1. Social presence teaching strategies

\begin{tabular}{|c|c|c|}
\hline $\begin{array}{c}\text { Cohesive teaching } \\
\text { strategies }\end{array}$ & Affective teaching strategies & $\begin{array}{c}\text { Interactive teaching } \\
\text { strategies }\end{array}$ \\
\hline Effusive greetings & Use of humor & Giving advice \\
\hline Thanking for participation & Sharing personal information & Prompting to answer \\
\hline Calling students by proper & Expressing feelings & questions \\
\hline names & Speaking in our mother & Keeping the video camera on \\
\hline Asking about students' & tongue & Expressing approval \\
\hline mental health & & Learning how to use the \\
\hline Asking for students' daily & & interface \\
\hline routine & & Congratulating on good jobs \\
\hline
\end{tabular}

\section{Cohesive teaching strategies}

I have to highlight that effusive greetings, thanking for participation, and addressing proper names in the new online environment are some of the issues regarding cohesive teaching strategies:

Hey, good morning! I am happy to have you here!

Hey, Carlos! Good morning, are you ok? What's new?

Good, Mary! Thanks for your participation!

I also asked my students about their family and mental health situation during the COVID-19 lockdown leading to social sharing: 
Betty, tell me about your family, are you living with them during your quarantine? How do you feel during this COVID-19 quarantine?

Regarding students' cohesive responses, answers to greetings were kind of passive and not quite enthusiastic:

$\mathrm{Hi}$

Hello

As a result, I had to prompt motivation to raise enthusiasm in our social presence:

Teacher: Hey, Luis what's up, be more energetic! HOW ARE YOU?

Student: Oh, teacher, I am pretty good, thanks, and you?

Asking for daily routine during their lockdown was an important cohesive element in the remote English course. They not only mentioned academic activities but also their chores:

Teacher: Mary, I would like to know about your daily activities during this lockdown, can you describe them, please?

Student: Well, teacher, I wake up at 7.00, take a shower, have my lunch and then I attend my virtual classes. At noon, I help my mom to cook lunch. Then, I wash the dishes... at night I do my homework and I watch television. Finally, I go to bed at 11.00 .

I also asked them to describe some of the activities that help them relax during this quarantine and these included listening to music, watching movies or Netflix series and practicing indoor sports. In order to give other ideas to relax, I asked them to preview the following link https://www.cnbc.com/2020/03/20/relaxing-activitiesto-do-at-home-during-covid-19-quarantine.html and then did some reading and speaking activities with them. Finally, it is worth noting that these cohesive strategies helped bond the group during Covid-19 times.

\section{Affective teaching strategies}

One of the strategies to raise motivation has to do with affective issues. Krashen (1981) argues that leaners need to have a relaxed atmosphere in language acquisition. Although the author makes a difference between acquisition (unconscious) and learning (conscious, a rational process) the affective filter concept is a good mechanism to be taken into account in pandemic times. Some students are motivated to learn a language, but high levels of stress or anxiety may cause the learning process a problem 
especially when they are beginners. As a matter of fact, motivation, self-esteem, and anxiety are affective factors that are present when learners are exposed to in a specific language. According to Krashen (1981), learners may have a mental block if they have low motivation, low self-esteem, and low anxiety, and this leads to increase the affective filter. Thus, there must be a good connection between learning and affect for language learners. The role of the teacher is then crucial to lessen the said filter and he/ she has to be creative in the teaching processes. In fact, I used different strategies to prompt affective issues. Using humor, sharing personal information, expressing fear, and speaking in our mother tongue were some of the elements that belong to this section, in order to have a relaxed atmosphere.

As a way to lessen anxiety, I began the first online session talking in our mother tongue (Spanish). I showed learners how to use the platform and recommended some tips in this interface:

Turn off the cameras and microphones if not being in use.

Use the chat if you have questions.

Find a quiet and comfortable place to attend English classes.

Make sure to install the software required properly.

I also used Spanish to talk about our feelings during COVID-19 quarantine and they expressed:

Feeling fear of catching COVID-19.

Not concentrating too much in classes.

Family members sometimes having troubles.

Economic troubles may be around.

Longing to return back to face-to-face classes.

Moreover, I asked students if they had pets at home and dogs and cats were the most common ones. Then, I prompted learners to use the video camera to show them and talk a little bit about them. This strategy was used as a way to lessen students' anxiety, too.

Another teaching strategy used was humor. In each session, I used different strategies to make my students laugh depending on the situation:

I asked volunteers to describe their families, "any volunteer? But using proper names in order to prompt humor: Yes, Peter you are my first volunteer, ha, ha, ha! 
I was drinking a cup of coffee and I placed my coffee close to the camera and invited them to drink it and students thanked me using the chat with ha,ha,ha.

I tried to figure out how to use some of the icons of the platform interface and my image appeared as if I were in three dimensions. I then told my students that this was the movie Matrix and I was Mr. Anderson.

Finally, these affective strategies helped learners feel a little bit more relaxed in these difficult times.

\section{Interactive teaching strategies}

My last social presence strategy involved giving advice and it is divided into both academic and personal issues:

Hey, guys, you have to keep busy during our COVID-19 quarantine.

You have to be patient during this time.

Find a quiet place at home to attend virtual classes.

Please update in all your academic activities.

Another piece of advice included motivation to keep on attending virtual classes. I also asked students to click on this link https://www.youtube.com/ watch?v=6W1e9edvk34 as a way to raise awareness and have critical discussions in order to maintain the university active in these emergency times.

The second strategy used was to prompt students to answer questions. At the beginning of our virtual sessions, students' participation was really difficult, as they did not participate on their own. Thus, I had to call out their proper names to participate in specific learning exercises:

Hey, John, can you answer the first exercise, please?

María, what's the answer in exercise 2?

On the other hand, I usually maintained my video camera on as a way to show my presence in that educational context. This might show my students companionship in the learning process. Moreover, I did my best to smile in front of the camera to have a relaxing and friendly environment. Finally, I used my body language to show approval (nodding, ok with my finger) when students did it well answering or interacting during the classes. 
Another important element was given at the very beginning of my ERT experience. I had to explore the interface myself and then showed my students how to do it. But first, I asked if they had joined online courses before and some of them agreed but not all of them. Thus, I showed them all how to use the interface as a way to interact not only with the system but also with participants.

Congratulating when students did a good job in their academic activities is an appropriate social strategy to consider. In fact, I always congratulated and thanked them when they did things right:

It was a good exercise Mary, congratulations and thanks for your participation.

Good job, John, great! Thank you very much for your participation.

Finally, and as a way to have an active social presence, I asked students to do some reading and speaking activities individually and in groups. Regarding the reading part, I asked students to surf the web in order to find web sites that contain information about sports or activities they might like doing at home during Covid times, as way to prompt motivation (Bradford, 2007; Dörnyei, 1998; Engin, 2009). I reminded them to apply some of the readings strategies when surfing the web: previewing (exploring the text and getting a general idea of it), scanning (locating specific information), skimming (obtaining a general overview), and intensive reading (focusing and analyzing important parts). Later, students shared their findings and reported orally their favorite activities or sports. Dancing, listening to music, playing musical instruments, cooking, doing yoga, spot jogging, watching tv series were some of ideas reported. I then asked students to ask their peers specific information about their activities (when, what time, how often, among others). After that, I selected some students to share their screens and asked them to read aloud some parts of their activities. Finally, I asked students to give their points of view about these activities during the pandemic times and ideas such as feeling relaxed, being active, being busy, having good mental health were given. As a result, there was interaction among participants.

One of the activities or topics of this language level has to do with interviews and I asked students to work in groups in order to prepare and perform an interview. It is worth noting that I first introduced the topic as a way to guide students to do this activity (importance of interviews, structure and vocabulary, possible questions, use of formal language, body language) and played a short video as an example. Then, I asked students to get in pairs to act out an interview and gave them some time to do it. Finally, they presented the activity, but some students were kind of timid. As a way to make them feel more active, I told them that all of them would have good grades just with the performance participation. As a result, their participation was more active leading to extrinsic motivation (Burden, 2004; Vansteenkiste, Lens, \& Deci, 2006). 


\section{Conclusions and recommendations}

Due to the coronavirus disease 19 (COVID-19), many educational institutions had to move their face-to-face classes to online classes in a sudden way. In this reflection I have described the social presence strategies during my Emergency Remote Teaching (ERT). The first element to highlight is to lessen students' anxiety in this foreign language course. The use of our mother tongue (Spanish) is crucial as learners are experimenting a new modality. Kayaoğlu (2012) argues that the use of mother tongue is an auxiliary tool for teaching languages. The use of humor is another positive element to lessen anxiety and students might feel relaxed and willing to participate. Moreover, it is important to show participants and give examples of how to navigate and use the different tools the platform offers in order to lessen anxiety, too. The second element during this COVID-19 lockdown is to introduce people as human beings and touch their realities. As a matter of fact, it is vital to prompt their feelings, talk about their surroundings, and give advice during interactions. It is also important to call out students by their proper names as a strategy not only to participate but also to link the sense of an academic group. Working in pairs or groups is another element to have social presence in this sudden modality. In fact, it is vital that students exchange ideas and give their points of view as a way to have social contact. Finally, congratulating and thanking are good elements to motivate students due to the fact that they are important characteristics in human interactions. It is worth noting that my teaching experience had to do with real practice regarding social presence in ERT times. This social interaction helped us maintain the learning process going on and the call to preserve the educational process active is a must in difficult times. Even this simple pedagogical description might guide other practitioners to think of other strategies to guide students in their learning process.

Regarding recommendations for foreign language teachers, it is necessary that teachers prepare or design activities that include not only the four skills, but also interaction among students. Students have access to different social media applications and for sure they find the best way to interact with each other. So, the task for the teacher is to design activities that motivate learners to work in groups. The second recommendation has to do with assessment. Take-home exams, self-assessment, and peer-assessment (Shohamy, 2001; Picón-Jácome, 2013; Bengtsson, 2019) are just some of the ideas to consider in this ERT due to COVID-19. The third advice is to monitor the ongoing process. The call to evaluate the process becomes a must in this ERT in order to make adjustments during the process. Finally, teachers should try new social interactions or ideas to see if they work. The concept of learning by doing (Li, 2015; Likitrattanaporn, 2017) is applicable in this modality. 


\section{References}

Bengtsson, L. (2019). Take-Home Exams in Higher Education: A Systematic Review. Educ. Sci., 9(4), 267.

Blessinger, P., \& Bliss, T. J. (2016). Introduction to open education: Towards a human rights theory, Open Education: International Perspectives in High Education. Cambridge, Reino Unido, Openbook Publishers, 11-30. https://doi.org/10.11647/ OBP.0103.01

Brand, A. (2007). Motivational orientations in under-researched FLL contexts: Findings from Indonesia. RELC Journal, 38(3), 302-323.

Burden, P. (2004). An examination of attitude change towards the use of Japanese in a university English 'conversation' class. Class, 35(1), 21 - 36.

Canale, M., \& Swain, M. (1980). Theoretical bases of communicative approaches to second language teaching and testing. Applied Linguistics, 1(1), 1-47.

Celce-Murcia, M., Dornyei, Z., \& Thurrell, S. (1995). Communicative competence: a pedagogically motivated model with content specifications. Issues in Applied Linguistics, 6(2), 5-35.

Creswell, J. (2012). Educational research: Planning, conducting, and evaluating quantitative and qualitative research. United States: Pearson - Prentice Hall.

Dörnyei, Z. (1998). Motivation in second and foreign language learning. Language Teaching, 31(3), 117-135.

Engin, A. O. (2009). Second language learning success and motivation. Social Behavior and Personality, 37(8), 1035-1041.

Esani, M. (2010). Moving from face-to face to online teaching. Educational Technology 23(3), 187-190.

Garrison, D., Anderson, T., \& Archer, W. (2001). Critical thinking, cognitive presence, and computer conferencing in distance education. American Journal of Distance Education, 15, 7-23.

Hodges, C., Moore, S., Lockee, B., Trust, T., \& Bond, A. (2020). The difference between emergency remote teaching and online learning. Retrieved from https:// er.educause.edu/articles/2020/3/the-difference-between-emergency-remoteteaching-and-online-learning 
InstitutoCervantes,(2002).Enfoquecomunicativo.Retrievedfromhttps://cvc.cervantes. es/ensenanza/biblioteca_ele/diccio_ele/diccionario/enfoquecomunicativo.htm

Kayaoğlu, M. (2012). The use of mother tongue in foreign language teaching from teachers' practice and perspective. Pamukkale Üniversitesi Eğitim Fakültesi Dergisi, Sayı 32 (II), 25-35.

Krashen, S. D. (1981). Bilingual education and second language acquisition theory. Schooling and language minority students: A theoretical framework, 51-79.

Li, F. (2015). Teaching and learning English by doing. International Journal of Language and Linguistics, 2(5), 156-162.

Likitrattanaporn, W. (2017). The development of English language teaching skills for graduate students through the process of learning by doing. English Language Teaching, 10(7), 96-103.

Mykota, D. and Duncan, R. (2007). Learning characteristics as predictors of online social presence. Canadian Journal of Education, 30(1), 157-70.

Nokukhanya, N., Chuks, E. \& Masuku, M. (2021). Emergency remote teaching in higher education during Covid-19: Challenges and opportunities. International Journal of Higher Education, 10(5), 1-9.

Picón-Jácome, E. (2013). La rúbrica y la justicia en evaluación. Ikala, 18(3), 79-94.

Redmon, P. (2011). From face-to-face teaching to online teaching: pedagogical transitions. Proceedings Ascile 2011 Hobart, 1050-1060.

Rourke, L., T. Anderson, D. R. Garrison, and W. Archer (2001). Assessing social presence in asynchronous text-based computer conferencing. Journal of Distance Education 14(2), pp. 50.

Rovai, A. P. (2002). Building sense of community at a distance. The International Review of Research in Open and Distributed Learning, 3(1). Retrieved from http:// www.irrodl.org/index.php/irrodl/article/view/79/152

Savignon, S. (2001). Communicative language teaching for the twenty-first century. In: Celce-Murcia, Marianne (Ed.), Teaching English as a Second or Foreign Language. (pp. 13-28). Heinle \& Heinle, Boston.

Shohamy, E. (2001). Democratic assessment as an alternative. Language Testing, 18(4), 373-391.

Stake, R. (1998). The art of case study research. Thousand Oaks: SAGE Publications, Inc. 
Sung, E., \& Mayer, R. E. (2012). Five facets of social presence in online distance education. Computers in Human Behavior, 28(5), 1738-1747. Retrieved from http://dx.doi.org/10.1016/j.chb.2012.04.014

Swan, K. (2019). Social presence in online learning. What's the big deal? Retrieved from https://es.slideshare.net/alexandrapickett/karen-swan-social-presence-inonline-learning-whats-the-big-deal

Swan, K. \& Shih, L-F. (2005). On the nature and development of social presence in online course discussions. Journal of Asynchronous Learning Networks, 9(3), 115136.

Vansteenkiste, M., Lens, W., \& Deci, E. L. (2006). Intrinsic versus extrinsic goal contents in self-determination theory: Another look at the quality of academic motivation. Educational Psychologist, 41(1), 19-31.

Yin, R. (2003). Case study research. Design and methods, (3rd ed) Thousand Oaks, CA: SAGE Publications.

\section{Author}

*Sergio Alonso Lopera holds PhD and MA in linguistics; specialist in teaching foreign languages. His research interests involve teaching $\mathrm{EFL}$ reading comprehension and pragmatics. He is a member of the research group EALE (Enseñanza y Aprendizaje en Lenguas Extranjeras) and a full time professor at Universidad de Antioquia (Medellín - Colombia).

ORCID: https://orcid.org/0000-0003-2773-0890

How to reference this article:Lopera, S. A. (2021) Social presence in an Emergency Remote Teaching (ERT) in English during Covid-19. GIST - Education and Learning Research Journal, 23, 169-182. https://doi.org/10.26817/16925777.967 